\title{
Environmental Change Impacts on Indus Riverine Forest, Sindh, Pakistan: Review
}

\author{
M. Amanullah", ${ }^{1,}$ and A. Ahmed ${ }^{2}$ \\ ${ }^{1}$ Centre for Environmental Sciences, \\ University of Sindh, Jamshoro, 76080, Pakistan \\ ${ }^{2}$ Aalborg University, \\ Department of Development and Planning, Aalborg, Denmark \\ ${ }^{\#}$ Corresponding Author: \\ Tele: (86) 18829786 124; E-mail: aman.mahar@usindh.edu.pk
}

\begin{abstract}
The lower Indus Basin lies in the Sindh province of Pakistan which has been divided on the basis of climatic and geographical factors. Climatically, it is classified into upper and lower regions called Upper Sindh and Lower Sindh. Geographically, Sindh is specifically distributed in three regions i.e., hilly tract in the west, alluvial plain in the centre and sandy desert in the east. Indus River flows in the centre of alluvial plain from north to south spread over $600 \mathrm{~km}$ and these areas are environmentally significant. Block of different forests are existed on the both banks of River Indus and termed as 'Riverine Forests'. These forests are ecologically important due to its complex ecosystem dominated by trees including environmental components. Smooth flow of Indus River during monsoon is the only lifeline for the survival and successful growth of these forests. Indus River is under the environmental stress i.e. diversion of river water for agricultural use coupled with naturally occurring drought, the riverine forests and its associated biodiversity has been negatively affected due insufficient water flow during forest's growing season which resulted in reduced function and productivity of forest ecosystem to a significant level. Whereas, other socio-economic and managerial issues have worsen the condition riverine forests ecosystem to such a degree that they are fading away from the land. Over the years, several attempts were made to rehabilitate forest ecosystem but resulted in vain due to lack of in-depth study of causes of general degradation. This review article aims to analyse past and present management practices of Riverine Forests and based on current review study; recommendations are being suggested for the sustainable forest management practices.
\end{abstract}

KEYWORDS: Change impact, Decline, Indus River, Riverine forest 


\section{Background of Study Area}

Sindh is the southern province of Pakistan which lies $26^{\circ} 28^{\circ}$ North latitude and 69 -71 E longitudes (Figure 1). It spreads to the Punjab and Balochistan provinces in the north, the Arabian Sea and the Runn of Kutch are in the south and Indian State of Rajasthan in the east. Sindh occupies $17.7 \%$ of the whole country with total land area 14.09 million ha (34.82 million acres). It establishes the lower part of Indus Basin which is recognized as cradle of Indus civilization. Sindh is divided into three geographical regions i.e. the rocky region in west, the sandy desert in the east and alluvial plain in the centre whereas it meets the Arabian See in the south (WWF-Pakistan, 2008). Riverine forests are located along both sides of the Indus River embankments and stretches over more than $1000 \mathrm{~km}$ distance and in the end it meets with Arabian Sea. This article has reviewed different research studies reports and document of national and international non-governmental organizations including stockholder departments of provincial Sindh government of Sindh. Moreover, authors belong to the study areas, their critical analysis and point of view about the state of the forests and interlinked complexities are logically discussed.

\section{Indus Riverine Forests}

In the central alluvial plains of Sindh province, forestry is the major land-user after agriculture. The Sindh forest department is the custodian of only $2.3 \%$ forest resources which possesses $8 \%$ of its total land area (ADB, 1988). It spread over 0.6 $\mathrm{M}$ acres $(0.24 \mathrm{M} \mathrm{ha})$ and it receive inundation waters received during wet season (Figure 2). During 1860 to 1960, earthen embankments were erected on the both sides of Indus River up to 6-22 km apart (Abichandani, 1940). These embankments are one of the significant part of riverine belt and owe their existence to the uncontrolled flooding/inundation of Indus River. Therefore, sustainability of forest ecosystem solely depends on the regular inundation supplies. The dominant tree species of Indus Riverine Forest are Acacia nilotica (local name: babul), Prosopis cineraria (local name: Kandi), Tamarix aphylla (local name: Lawa), Tamarix dioca (local name: Lai) and Populus euphratica (local name: Bahan) restricted to well drain high silt containing stabilized kacho areas (riverine belt). Mesquite growth has invaded high lying areas which are quite useful for fuelwood and charcoal making (Ahmed, 1970).

\section{Irrigated Forests}

Along both sides of Indus River, 81,200 ha of Riverine forest were reduced as inland forests after construction of earthen embankments (bunds) with the construction of three barrages on Indus River for providing river water for agriculture and canal water was diverted for many inland forests for converting these into irrigated forests (Al-Mubarak, 1975). Inland forests falling in the command of each barrage are as under: Guddu Barrage command area $=0.02$ million ha ( 0.05 million acres), Sukkur Barrage command area $=0.04$ million ha (0.09 million acres) and Kotri Barrage command area $=0.03$ million ha $(0.07$ 
million acres) with of total 0.08 million ha ( 0.20 million acres). In order to supply firewood to railway, ships, fuel wood for cantonments steam boats and steam boats, the idea of irrigated plantation was initiated during the British Rule in the territory of Sindh. The dominant tree species of irrigated plantation are Dalbergia sissoo, Acacia nilotica, Salmalia malabaricum and Eucalyptus camaldulensis (Anon, 1983).

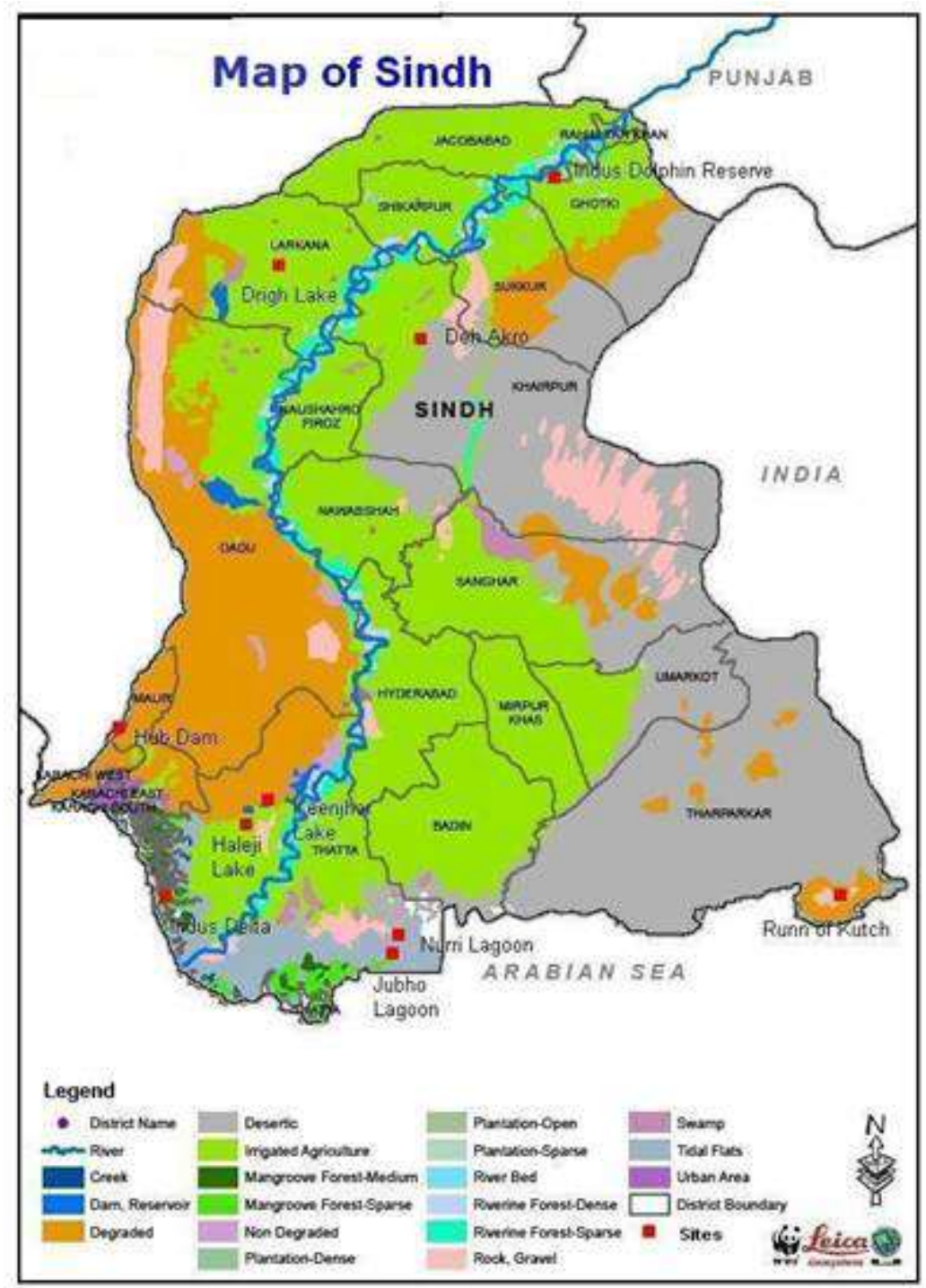

Figure 1: Map of Sindh

(Source: WWF-Pakistan, 2008) 


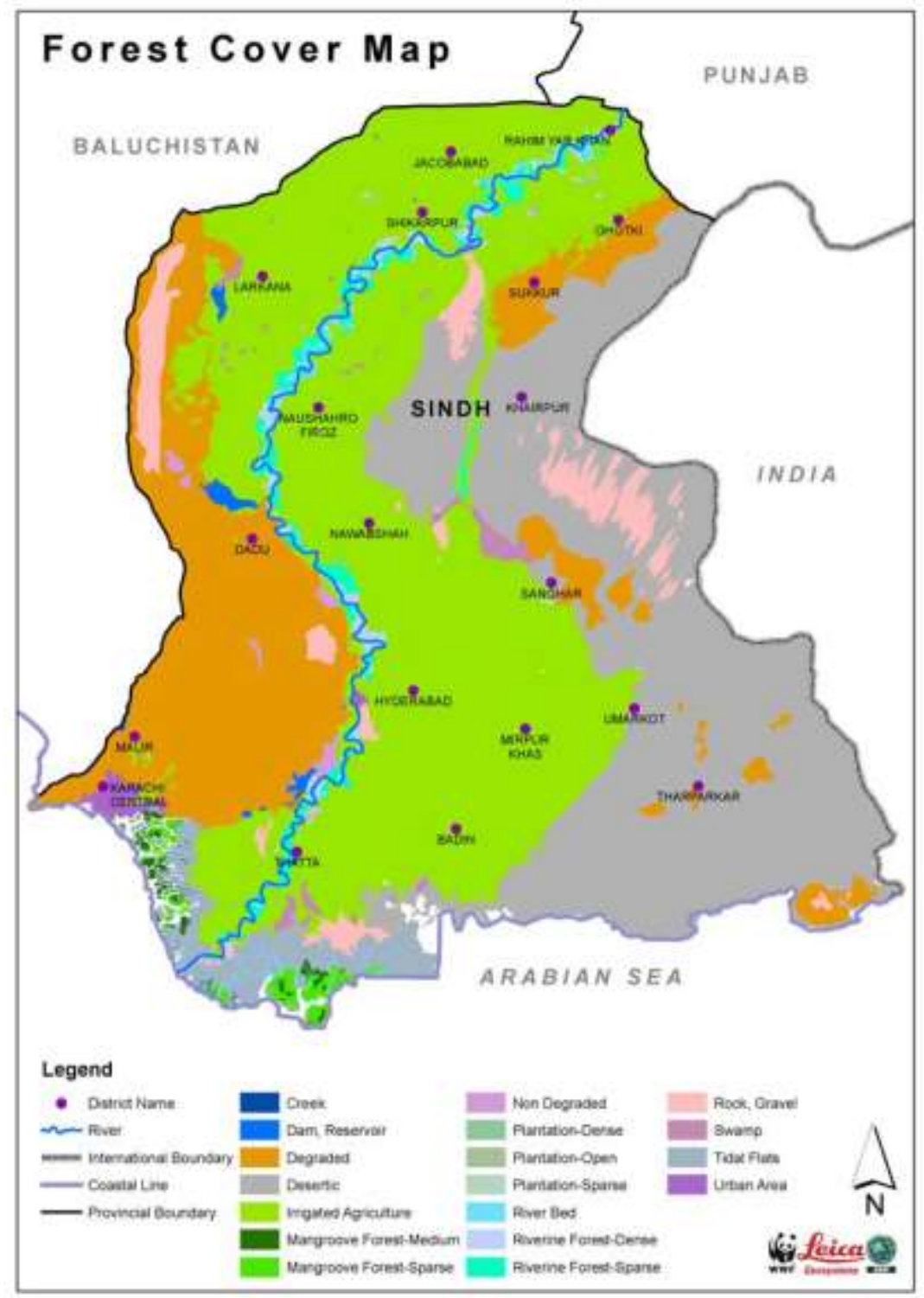

Figure 2: Forest cover map of Sindh province

(Source: WW-Pakistan)

\section{Historical Perspective of Sindh Riverine Forests}

\section{Pre-British Rule History of Riverine Forests}

Before the conquest of Sindh by British Empire, the annual inundations were nearly unchecked across central alluvial plain of Sindh. The cultivation and population were a part of what these are today (Advani, 1943). The forests were flourished all over the available land where it received water. Afterwards, local people started to 
cut forests, cultivated crops and made temporary settlements wherever they liked which resulted in the segregation of wooded area into blocks and patches, which to a large extent characterized as the riverine tract today.

The Mirs (Royal Family \& Rulers of Sindh) had reserved some of the riverine forests for hunting purpose, mud walls were erected around these confined areas and strictly protected under game laws (Aitken, 1907). In 1843, when Britishers conquered Sindh then these game reserves became the center of present day forests. However, there is no record that when game reserves were demarcated as forests, but in the year 1847 Major Scott was appointed as the first Forest Ranger in Sindh (Beeson, 1941). Mr. Fenner was given the charge of these forests in 1861. Sindh Forest Department was established in 1862 and custody of these forests was transferred from railway companies to Sindh Forest Department. The procedure for declaration of specific lands as legal forests was stipulated under the general application of the Indian Forest Act in 1863. The remaining lands were constituted as wastelands for pasture/grazing. During this time, requirement of fuel wood was increased due to establishment of railway lines between different parts of the Sindh including Karachi, Kotri, Dadu, Larkana, Ruk and Sibi and later between Rohri and Samasata (Aitken, 1907).

\section{Management of Riverine Forests during British Rule Period}

There is no record available about the managerial system of these forests, as no administration reports are existed for that period till 1860-61 before the period of Sindh conquest by British Empire. However, Local rulers and communities were looking after these woodlands for hunting purpose (Anon, 1986). The management also does not exist during 1860 - 1895 on any systematic plan of reproduction and harvesting. Local population had exploited the forest resources to meet their demand, Indus Flotilla Company - a British military Company and subsequently for the state railway when railway took the place of steam boat navigation (Anon, 1987). In the initial period, the disposal system adopted were shared and royalty methods, that were later substituted by departmental working. Departmental working continued up to 1901, when the system of selling coupes by tender or by auction was introduced (Aitken, 1907).

\section{Current Management Practices of Riverine Forests}

In order to generate/regenerate Acacia nilotica, the management objective of these forests was set, which is the most stable tree species with short rotation period and high economic value. Acacia nilotica takes a longer time to grow or regenerate in its natural succession as it follows a growth cycle which is preceded by Tamarix, Saccharum and Populus euphratica growth. Acacia nilotica regenerates when favourable conditions and new soil formation are created in the riverine tract (Panhwar, 2004). In order to speed up the process and grow Acacia in a shorter period, broadcast sowing is done in muddy waters during recession of floods each year (Amjad, 1984). Management practices have been simple and time tested. The 
forest areas on attaining rotation period are marked for clear felling in the form of 64 ha (one compartment) or smaller coupes for felling operations. Clear felled coupes/areas and newly stabilized kacha areas are regenerated as inundation recedes after the peak flood season (Anon, 1973).

\section{Degradation of Riverine Forests and Reasons Behind}

Historically, the riverine forests of Sindh were economically viable and productive, but the socio-economic pressures, destruction caused by anthropogenic and natural factors and climatic changes and have considerably degraded and depleted this ecosystem. The ecosystem functions as chain or web where the biotic and abiotic factors function as its string (Stoszek, 1991). Any natural or anthropogenic change in any form disturbs the whole web. More the disturbance, the higher the complexity of interactions within the ecosystem leads to a catastrophe. In this regard, the highly susceptible components of ecosystem are the living organisms towards any negative impact. The factors described here are both natural and anthropogenic but their magnitude has been exacerbated by the intentional and unintentional activities of human beings (Anon, 1983).

\section{Population Pressure on Riverine Forests}

Sindh is the most urbanized and populous province of Pakistan. It accommodates 30.4 million people with a density of 135 persons per sq. $\mathrm{km}$ according to 1998 census report. The projected population will reach $48 \mathrm{M}$ in 2015 and $56 \mathrm{M}$ in 2020 with annual increase rate of 2.8 percent (IUCN, 2004). 72 percent of the population in Sindh province is depended on agriculture which is mostly practiced in the central zone which is resulted in thickly populated irrigated tract and put direct pressure on riverine forests. Due to increasing population, the destruction of riverine forests has accelerated. However, all the biodiversity of riverine forests have been damaged particularly trees are badly affected due to population pressure. In order to meet the need of domestic fuel wood and livelihood, the indiscriminate tree cutting has exacerbated the condition of already fragile ecosystem. People have also encroached upon forestland for agriculture purposes. More than 40,000 ha of riverine forests of Sindh have been encroached (Anon, 1986).

Such practices have resulted in the total destruction of ecosystem biodiversity i.e. loss of wildlife habitat, soil degradation, disappearance of associated fauna and flora, decrease in gene pool and change of micro climate have changed over all environmental scenario of the area. This has ended in the decreasing the horizontal and vertical structures of riverine forests (Sirhindi and Keerio, 1987). The population living in Kacho area (Riverine Belt) and adjoining areas depend either directly or indirectly on the riverine forest resources. It is generally observed that the people living within riverine forests or its vicinity mostly depend on riverine forests for meeting their domestic needs. According to an estimate (IUCN, 1991), people living within $5 \mathrm{kms}$ of forests are dependent on riverine forests to the extent 
of 50 percent, whereas 30 percent needs of the people residing up to $10 \mathrm{kms}$ are met from riverine forests.

\section{Impacts of Regional Climatic Change}

The vegetation is a function of climate, soil, topography, parent material, time and biota. Of these factors, climate is generally accepted as one of the major determinants of vegetation type (Kimin, 1987). It affects the productivity and suitability of tree species on specific area and influence every angle of forest management from regeneration to harvesting. The important climatic factors widely discussed and analyzed are temperature, rainfall, humidity, wind and their interaction with respect to duration and availability of water for the survival and growth of riverine forests (Kimin, 1987). These components have direct or indirect effect on the growth and occurrence of different species in these forests. There has been a substantial deterioration in riverine forests due to climatic factors over the time period (Kimin, 1987).

The rainfall is very short and does not meet the moisture requirement of trees for their required growth in the riverine forests of Sindh. The provincial data of rainfall shows that northern part of the province receives almost half the quantity of rainfall than its southern part, which considerably impacts the development and growth of riverine forests. The rainfall mostly occurs during the monsoon season i.e. from June to August (Panhwar, 1964). The rest of the year remains mostly dry and unfavorable for tree growth. Leading species in the riverine forests is Accacia nilotica which needs adequate moisture and does not grow in harshly dry conditions. In the upstream Sukkur, except for the low lying areas or areas in the immediate upstream of Sukkur barrage, Accacia nilotica does not grow well and xerophytic Prosopis cineraria takes its place as dominant species and it is more evident in the areas which are high lying and out of reach of normal inundation water (ADB, 1988).

Apart from rainfall, the periodical temperatures have effect and influence on overall climate of the lower Indus plain, which ultimately effects the riverine ecosystem in that area (Billing, 1970). Based on the temperature regime, Sindh has two different parts i.e. upper Sindh and the Lower Sindh. The meteorological data (IUCN, 2004) shows that there is no significant difference in mean annual temperatures between two eco-zones, but there is significant difference in hot and cold seasons. This change in the temperature associated with other factors such as edaphic, biotic and socioeconomic considerations effect the distribution, growth, composition, and establishment of flora and fauna in general and tree species in specific. Trees and plants species in riverine tract grow well in the temperature range of $23^{\circ} \mathrm{C}$ to $35^{\circ} \mathrm{C}$ (Troup, 1921). Under these conditions, these regions are quite suitable for the establishment and growth of indigenous plant species (Troup, 1921).

It also specifies the variations in duration of mean temperatures and hot season of upstream Sukkur and downstream Kotri areas which gradually influence each 
component of riverine forests. The maximum temperature reaches to $50^{\circ} \mathrm{C}$ upstream Sukkur, whereas it occasionally crosses $40^{\circ} \mathrm{C}$ below Kotri. Hot temperatures regimes for longer period coupled with humid conditions and low rainfall create dry conditions around upstream Sukkur riverine tract whereas moderate temperature, high humidity with relatively higher rainfall makes the climate moderately dry below Kotri (Keerio, 1990). The most common harmful effects of high temperatures are the excessive loss of moisture and the stimulation of the excessive respiration (Kimin, 1987). The impacts of increased soil temperatures have important effect on trees foliage of seedlings in the regeneration areas because of the direct heat and decreased soil moisture.

The capability of plants to resist freezing temperature is a function of its genetic potential and environmental factors which tend to condition tissue for cold treatment (Stoszek, 1991). Accacia nilotica, the keystone tree species of riverine forests is a frost tender species. Large areas of young seedlings in the newly regenerated sites in the forests and farmlands are damaged or even killed due to injuries caused by persistent frost bites. The damage is at times so severe that younger plantations of Accacia nilotica die back to the ground (Sirhindi and Keerio, 1985). Late frost is also common in the upper region of Sindh. Frost is not of common occurrence below Kotri due to proximity of the Arabian Sea. The interaction of humidity and wind with the rainfall and temperature constitute the climatic pattern of the two zones varying in every constituent aspect. There is also unmarked influence they impart on vegetation. The next section addresses water changes and connected impacts on riverine forests.

Because of wind direction and velocity, there is a considerable difference in the climate of two ecological zones. Speedy humid winds blow almost all time from May to September in lower Sindh whereas in upper Sindh wind velocity is very low and less humid. These two climatic factors has great influence over the distribution of fauna and flora in these two eco-zones. As their influence on tree establishment and its growth, these two aspects have significant effect amongst them.

\section{Inter-Province Water Distribution in Pakistan and Its Impacts on Riverine Forests}

Indus River is the sole lifeline for the survival and sustenance of Sindh riverine forests. The extent of river water volumes, frequencies and occurrences of floods controls the water regime required for regeneration, enrichment and growth of vegetation and related components of riverine forests (WAPDA, 1991). The construction of barrages at the upstream of Indus River has deteriorated already fragile riverine forests resulted in considerable decrease in the frequency, intensity and extent of annual flooding. Diversions on Indus River because of the construction of canals and link canals have further exacerbated the ground conditions (WAPDA, 1991). Due to continuous receipt of low or no floods coupled with prolong droughts most of the riverine forests have not been inundated since last ten years. As a result, most of the original forest areas are now lacking of 
vegetation. The prevailing conditions will further worsen when new barrages and dams will be constructed as it is predicted. It is anticipated that only about 20 percent of the original forest site will get adequate inundations for its nourishment. Nowadays, as much as 50 percent of the original 0.238 million ha of riverine forests has deteriorated beyond the level of economic feasibility (ADB, 1988). The diversion of water into canal irrigation systems for agricultural purposes have further worsened the condition in the riverine forests. As large quantities of the water is used for agricultural purpose so excessive colonization will be bringing more land under the plough and it has made it impossible to accomplish the original afforestation plan objective.

The upcoming development programs of rehabilitating the degraded riverine forests is now completely dependent on one specific requirement of availability of inundation water periodically for nourishing the vegetation of ruined forestlands. In this case, definite water supplies for the riverine forests will only serve for future viability and tentatively of tree growth in the lower Indus Basin. A separate permanent share of water for the regular need of these forests has to be allocated and given priority to save the amazing biodiversity of riverine forests

\section{Reduced Floods}

Sindh used to get additional land area by formulation of deltaic land and silting process in delta pushing Arabian Sea backwards prior to 1932. After construction of Sukkur barrage, receiving of additional area almost ceased as relatively less water reached the sea due to spread of flood water in Kacho area and its diversion into canals. After construction of water reservoirs and several other barrages, frequency of water was significantly reduced towards the deltaic region and it started taking back the reclaimed land through sea intrusion (WAPDA, 1991). Climate changes influenced the Indus Basin and country experienced more droughts, than before. Population explosion, law and order situation, tribal feuds, un-employment and political disorder exacerbated the illegal tree cutting and encroachment of forestlands by influential local people and unscrupulous persons. Indus Delta has been significantly affected due to freshwater shortages below Kotri, reduction in flows during flood period and reduction in silt and nutrient flows. The primary effects of reduced water supplies cause salt water intrusion, changes in geomorphology of the delta and changes in nutrient balance of the ecosystem (IUCN, 1991).

\section{Droughts}

Wet and dry annual cycles are the common phenomenon of climatic regime but Sindh has experienced severe drought conditions between the years 1997 to 2003. Reduced floods due to low rainfall in the catchment areas are main reasons for this situation. This entire situation reveals that during the long drought period, there was a significant damage to the existing tree growth and failure to achieve annual regeneration plan targets. It was extremely alarming position in the forests 
downstream Kotri, where only one normal flood was received in seven years. As a result, large area was damaged and only 10 percent of regenerated area survived.

\section{Conclusions and the Way Forward}

Based on the prevailing state of riverine forest of Sindh, there is a dire need to frame a dynamic policy for the preservation and management of riverine forests which is the main stay of forestry in the province of Sindh. Furthermore, these forest play a significant role in environmental protection and preservation of biodiversity in Indus Ecoregion.

The following key points are suggested to protect the biodiversity of riverine forests of Sindh:

- There is an urgent need to initiate participatory management approach towards management and development of riverine forest In order to check the degradation, preserve and promote the biodiversity in Indus Ecoregion.

- Stackholder government departments should adopt policies and enact laws which provide opportunities to local communities to develop their management skills and incentives for long-term sustainable management of riverine forests. The communities should be mobilized, organized, empowered and trained in human ecology and conservation so that they may be partners in protection, production and economic benefits at mutually agreed conditions.

- Riverine forests should declared as 'biosphere reserves' to restrict anthropogenic implications for certain period of time and the ecosystem be allowed to develop naturally with minimum human interference.

- There is great scope of improvements in the present forest management strategies and policies so as to expand management responsibilities of forestry personnel to include human ecology and conservation.

- Forest department needs to start incentive programmes to promote farm forestry on private lands and community based woodlots on state arable lands to meet their fuel wood needs.

- In order to provide technical and material assistance to the farmers, forestry extension services be strengthened and reorganized for the promotion of tree growth in riverine tract, marginal and wastelands through people's participation.

- In riverine forest ecosystems, the research should emphasize on studies on the causes of success and failure in forest development, the impacts of 
water shortage on the forest resource; ecosystem functions, and suggests measures to make the ecosystem functional and productive. Surveys and analyses of the degree and extent of the subsistence and local use of forest products, marketing, comprehensive inventories and assessments should be conducted. Research trials for growing of suitable xerophytic species are required to be conducted in riverine areas.

- There is lack of database pertaining to different factors affecting riverine forests such as ecological, social, economic, technical, biotic and edaphic in the region. It is necessary for the future development to have a data bank in the Forestry Department.

- Presently there is no seed bank facility available in the Sindh Forest Department. In years, when high inundations are received or in bad seed years, sufficient seed is not available to meet the seed requirement for achieving planting targets. By this reason, it is essential that a seed bank should be developed where large quantity of quality seeds is stored for planting, coupled with sowing and supplying facilities to farmers.

\section{References}

Abichandani, C.G. (1940). "Revised working plan for upper Sindh forests".

Advani, A. N. (1943). "Artificial regeneration of Babul in Riverine Forests of Sindh". Indian For, 69 (2).

Ahmed, M. (1970). "Further studies on the leaf hopper of the Erythroneurini cicadellidae: Typhocybianae from West Pakistan”. Pak. Jou. Zoology, 2 (2): 167-184.

Aitken, E. H. (1907). "Gazetteer of the province of Sindh". Reprinted in 1986 by Indus Publications, Fareed Chambers Karachi.

Al-Mubarak (1975). "Feasibility report survey and investigation for rehabilitation of riverine forest of Sindh". Government of Sindh Document.

Amjad, M. (1984). "State of Forestry in Pakistan 1983”. Pakistan Forest Institute Peshawar.

Anon (1973). "Erosion and accession in riverine forests of Sindh". Forest Department, Government of Sindh.

Anon (1983). "Succession legacy in riverine forests ecosystem". Forest Department, Government of Sindh.

Anon (1983). "Effects of construction of upstream barrages and dams on Indus on water availability in Indus". Forest Department, Government of Sindh.

Anon (1986). "Position paper on Sindh Forestry Development". Submitted to World Bank. 
Anon (1987). "Population pressure on natural resources". A report submitted to NCA, Pakistan.

ADB (Asian Development Bank) (1988). "Feasibility study report of Sindh forests". Pakistan forestry master plan reconnaissance mission report.

Beeson, C. F. C. (1941). "Ecology and the control of the forest insects of India and neighbouring countries".

Billing, W. D. (1970). "Plants, man and the ecosystem". Wadsworth Pub. Press Co. Inc. Belmont, California.

IUCN (1991). "Indus delta mangrove ecosystem".

IUCN (2004). "State of the environment in Sindh".

Keerio, G. R. (1990). "Opportunities and problems of agroforestry- My Pakistani experience". Submitted for publication in Agroforestry Today, Nairobi, Kenya.

Kimin, J. P. (1987). “Forest ecology”. Mcmillan Publication Co. New York.

Panhwar, M. H. (1964). "Underground water survey of Sindh plain”. Government of West Pakistan Press, Lahore.

Panhwar, M. H. (2004). "The neglected riverine area of Sindh: The present situation and government's responsibility for its development". Water Scarcity in Sindh. Proceedings of the Seminar Environmental, Social and Cultural Impact of Water Scarcity in Sindh.

Sirhindi, B. and G. R. Keerio (1985). Position Paper on Forestry in Sindh (A report submitted to NCA, Pakistan).

Sirhindi, B. and G. R. Keerio (1987). Proposal for Forestry Development in Sindh (A report submitted to CIDA).

Stoszek, K. J. (1991). "New perspective in forestry".

Troup (1921). "Manual of Silviculture".

WWF-Pakistan (2008). "Study of Riverine forest upstream Sukkur and downstream Kotri”.

WAPDA (1991). Water Accord. 